\title{
Sociálne siete ako priestor pre tvorbu a fungovanie svojpomocných skupín pre rodičov detí s autizmom počas pandémie COVID 19
}

\author{
Social Networks as a Space for the Creation and \\ Functioning of Self-help Groups for Parents of Children \\ with Autism
}

Erika Ochabová1, Fakulta sociálnych vied UCM v Trnave, Trnava

\begin{abstract}
Abstrakt
V príspevku sa budeme zaoberat' významom sociálnych sietí, ktoré ponúkajú svojím užívatelom možnost' stat' sa členom skupiny, ktorá ich združuje na základe spoločného záujmu. Čitatelom chceme ozrejmit’ sociálne skupiny, ktorých hlavným predmetom fungovania je vzájomná pomoc rodinám detí s autizmom. V príspevku chceme poukázat' na význam a dôležitost' existencie online skupín, kde si členovia odovzdávajú dôležité rady, skúsenosti či poznatky. Rodičia detí s autizmom sa navzájom podporujú a pomáhajú si. Sociálne skupiny zamerané na pomoc rodinám detí so špecifickými potrebami si našli svoje uplatnenie aj počas pandémie, kedy bol osobný kontakt liudí medzi sebou zamedzený. Výskum bude realizovaný pomocou kvalitatívnej metódy zberu dát. Pološtrukturovaný rozhovor budeme viest' s rodičmi detí s autizmom, ktorí sú aktívnymi členmi online skupiny zameranej na autizmus. Cielom nášho príspevku je zistit', ako komunite rodín detí s je nápomocná online skupina a ako sa jej členovia navzájom podporujú.
\end{abstract}

\section{Klíčová slova}

sociálne siete, online skupina, autizmus, podpora, svojpomoc

\section{Abstract}

In this paper, we will deal with the importance of social networks, which offer their users the opportunity to become a member of a group that unites them on the basis of common interest. We want to make social groups clear to readers, whose main subject of operation is mutual assistance to families of children with autism. In this article, we want to point out the importance of online groups, where members share important advice, experience or knowledge. Parents of children with autism support and help each other. Social groups focused on helping families of children with special needs also found their application during the pandemic, when peopless personal contact with each other was prevented. The research will be carried out using a qualitative method of data collection. We will have a semi-structured interview with parents of children with autism, who are active members of an online group focused on autism. The aim of our paper is to find out how the community of children,s families is with the help of the online group and how its members support each other.

\section{Keywords}

social networks, online group, autism, support, self - help

\section{Úvod}

Opatrenia štátu v súvislosti s pandémiou COVID-19 špecifickým spôsobom vstúpili do života rodín s autistickým diet́at́om. Tieto deti vel'mi citlivo reagujú na akékol'vek zmeny a majú zhoršený adaptačný mechanizmus smerom k narušeniu ich stereotypov.

V našom výskume sa budeme zaoberat' tým, ako prežívajú rodičia detí s autizmom súčasnú pandemickú situáciu. Ako rodiny fungujú počas sociálnej izolácie, kedy sú zavreté školy pre deti s autizmom či denné

1 Kontaktní osoba: ochabovae1@ucm.sk 
centrá. Chceme zistit́ aké možnosti združovania sa majú rodiča detí s autizmom počas pandémie. Cielom je zistit', ako pandémia COVID-19 zasiahla život v rodinách s diet'atom, ktoré má diagnostikovanú poruchu autistického spektra.

\section{Súčasný stav poznaní}

\section{Pandémia COVID 19 a Autizmus}

Začiatkom roka 2020 sa vo svete, konkrétne v meste WU-Chan v Číne objavil nový, nepoznaný vírus, C0VID19, nazývaný aj koronavírus. Na Slovensku sa o prvom človeku nakazeného koronavírusom dozvedáme v marci v roku 2020. Vírus sa začal po celom svete šírit' nekontrolovatel'nou rýchlostou, čo spôsobilo, že všetky krajiny sa začali s prijímaním nových. Hlavnou úlohou opatrení bolo zamedzit́ šíreniu vírusu. Jedným z týchto opatrení bolo obmedzenie vychádzania a sociálnych kontaktov ludú. Postupne sa začali zatvárat́ základné, stredné i vysoké školy. Z dôvodu zamedzenia šírenia sa vírusu boli nútené svoju činnost' pozastavit́ aj niektoré sociálne zariadenia (MIVN, 2021).

V našom príspevku sa zameriavame na ciel'ovú skupinu rodín so školopovinnými det'mi, ktoré majú diagnostikovanú poruchou autistického spektra ako odberatel'ov sociálnej pomoci. Skúmat' budeme zmeny správania sa detí s autizmom, ktoré spozorovali ich rodičia počas uplynulých 12 mesiacov sociálneho odlúčenia. Pre osoby trpiace autizmom je známe, že títo l’udia sa využívajú v rituáloch, ktoré predstavujú presný plán dňa, podl'a ktorého sa autistický človek pravidelne riadi. Človek trpiaci autizmom zvyčajne nedodržuje stály očný kontakt, je nesústredený (Národný portál zdravia, 2021).

Online skupina na internetovej platforme Facebooku s názvom AUTIZMUS bola založená v dňa 12. marca 2018, doposial'má 1628 členov (Autizmus, 2021).

Online skupina na Facebooku s názvom PRIATELIA AUTISTOV bola založená dňa 25.12. 2010. V skupine sa nachádza 3428 členov, denne v skupine pribudne 5-10 príspevkov, v ktorých si rodičia detí radia, vymieňajú informácie či poskytujú cenné rady. Počas pandémie skupina zaznamenala vyšší prírast nových členov ako obvykle. Clenovia si medzi sebou zdielajú edukatívne videá pre svoje deti, odkazy na webináre či návody na hry, ktoré majú náučný ale i zábavný charakter počas pandémie, kedy dietatúu nie je umožnená návšteva školy či denného centra (Priatelia autistov, 2021).

\section{Online svojpomocné skupiny na sociálnych siet'ach}

Sociálne siete (často preložené v angličtine ako „stránky sociálnych sietí“, „sociálne siete“ alebo všeobecne „sociálne médiá“) sú podmnožinou takzvaných sociálnych médií a v súčasnosti sú najoblúbenejšou internetovou službou. Sociálne médiá patria do podskupiny médií a sú formou médií. Sú to platformy, ktoré umožňujú interaktívnu webovú stránku zapájaním použivatelov, komentovaním a vytváraním obsahu ako prostriedku komunikácie s ostatnými používatel'mi a verejnost́ou (Losekoot a Vyhnánková 2019).

Skutočnost', že sociálne siete sú založené na vzt'ahoch medzi používatel'om a používatel'om, robí sociálne siete úplne novým médiom. Tieto vztahy možno označovat' ako „priatel'stvá“ (napr. na Facebooku) alebo „následné opatrenia“ (napr. na Twitteri alebo Instagrame), hoci v niektorých prípadoch je to v podstate to isté - to znamená, že používatelia chcú medzi sebou komunikovat’ a zdiel'at́ informácie (Bednář 2011).

Svojpomocné skupiny sú podla stretnutia ludú, ktorí majú určitým spôsobom niečo spoločné a môžu si navzájom poskytovat́ emocionálnu podporu. Užívatelia mali v minulosti podobné skúsenosti alebo ich momentálne prežívajú. Najčastejšie sa ludia združujú ohl'adom pomoci pri strate blízkeho človeka, choroby, chronického zdravie alebo potrebujú pomôct́ pri závislosti. Taktiež môže íst' o zdielanie marginalizovanej identity, ako je sexualita, rodová identita alebo rasa, ktorá ovplyvňuje výzvy, ktorým čelia pri pohybe svetom. Toto je však len niekol'ko príkladov, na sociálnej sieti Facebook existuje vel'a svojpomocných skupín (Statista, 2020).

Na podporných skupinách je dôležité, že sa môžu líšitt vel'mi v praxi. Na rozdiel od skupinovej terapie, ktorú vedie licencovaný psychológ a ponúka cielenú podporu, existujú podporné skupiny v mnohých tvaroch a vel'kostiach. Niektoré podporné skupiny majú formu online komunít a nemajú žiadne stretnutia. Podporné skupiny na online sociálnych siețach môžu byt' vel'mi užitočné, ale nenahrádzajú profesionálnu starostlivost' o duševné zdravie.

Prostredníctvom strediska technickej podpory nájdete rôzne podporné skupiny. Kurátori sú svojpomocné skupiny od iných organizácií, ako je napríklad National Alliance On Mental Illness (NAMI), a d'alej: 
MIND. Skupiny môžete vyhl'adávat' podl'a tém, ako sú depresia, závislost', LGBTQ + a dokonca aj COVID-19. Sociálne skupiny na internetovej platforme Facebook, sú pre svojich užívatel'ov zadarmo, avšak každá skupina sa riadi pravidlami, ktoré musia jej členovia dodržiavat'. Pri porušovaní pravidiel môže byt' člen vyňatý zo skupiny (CNN Business 2019).

Na internetovej platforme Facebook sme vyhl'adali príspevky o autizme, ktoré nás priviedli až k dvom existujúcim Facebookovým skupinám s názvom AUTIZMUS a PRIATELIA AUTISTOV. Tieto skupiny sú zameraná na online pomoc, podporu či poskytovanie informácií o autizme. Jej členovia sú rodičia detí s autizmom, psychológovia, samotní l'udia trpiaci poruchou autistického spektra. Súčastó skupín na sociálnej sieti sú aj bežní l'udia, ktorí prejavujú osobný záujem dozvediet' sa nové informácie priamo od ludú, ktorí sa s autizmom stretávajú denno-denne. Členovia si odovzdávajú vlastné postrehy, cenné rady, ktoré nadobudli počas života v spoločnosti s autistickým členom rodiny či priatel'om (AUTIZMUS, 2021).

V súčasnom online svete, ktorý prevláda nad spoločenským životom, prinútil rodičov detí s autizmom k domácemu vzdelávaniu. Rodičia si medzi sebou zdiel'ajú edukatívne videá či online hry, ktoré majú nie len náučný charakter ale aj deti zabavia v domácom prostredí počas sociálnej izolácie (Priatelia autistov, 2021).

\section{Autizmus}

Autizmus je v súčasnosti považovaný za neuro-vývojové postihnutie mozgových funkcií s vel'mi významnou dedičnou zložkou. Výsledkom je, že človek atypicky vníma, spracováva, vyhodnocuje a reaguje na informácie pochádzajúce z okolia, ako aj na svoje vlastné skúsenosti (napr. to, čo vidí, počuje, cíti, cíti), nie je schopný primerane komunikovat', nadviazat' sociálne vztáahy alebo rozvíjat' predstavivost', predstavivost' a kreativitu. Je to jedna z najzávažnejších porúch duševného vývoja detí a jej prejavy znevýhodňujú osobu s autizmom počas celého svojho života.

Podla súčasných kritérií je diagnóza autizmu a iných porúch autistického spektra založená na prítomnosti širokej škály špecifických prejavov správania a ich umiestnení v kontexte vývoja jednotlivca. Tieto prejavy môžu byt' vel'mi rôznorodé, môžu byt' reprezentované v rôznych stupňoch a frekvenciách a majú tendenciu sa menit' počas celého vývoja. Niektoré môžu časom oslabit' alebo zmiznút', zatial'čo iné sa prehĺbia. Vhodné zásahy alebo úpravy životného prostredia môžu zmiernit' niektoré prejavy autizmu, zvýšiț šancu na adekvátnejšie zvládnutie špecifických situácií alebo celkovo úspešnejšie fungovanie jednotlivcov v každodennom živote. Poruchy autistického spektra majú často pridružené poruchy a choroby, ktorých prítomnost' môže st́ažit' diagnostiku a následnú intervenciu (Beyer, Gammeltoft, 2006).

\section{Metoda}

V d’alšej časti nášho príspevku sa zameriame na pilotný výskum, ktorý sme realizovali pomocou kvalitatívneho zberu dát. Kvalitatívny prieskum je zameraný na skúmanie javov a následné analyzovanie vztáahov, príčin a súvislostí medzi nimi. Realizuje sa na malom počte zástupcov vybranej ciel'ovej skupiny. Jednou z výhod je získavanie informácií v pomerne krátkom čase. Je tiež vhodný pre skúmanie akejkol'vek témy. Popisuje príčiny správania sa liudí, ich názory a postoje (Hendl, 2015).

Na základe štúdia odbornej literatúry sme na zber informácii do výskumu zvolili pološtrukturovaný rozhovor. Hovoríme o takom rozhovore, v ktorom má autor pripravenú schému otázok, ich poradie a znenie však nemusí striktne dodržiavat́. Prvá čast' otázok je vopred pripravená, druhá sa odvíja od priebehu rozhovoru a v závere je priestor na vlastné vyjadrenie respondentov. V rámci daného druhu rozhovoru je poskytnutý priestor pre subjektívne názory respondentov, možnost' klást́ dodatočné otázky, pre presnejšie vysvetlenie alebo ponúknut alternatívne odpovede (Žiaková, 2009).

Súčasná pandemická situácia nám návštevu sociálnych zariadení vel'mi skomplikovala.

V online skupinách na Facebooku s názvom AUTIZMUS a PRIATELIA AUTISTU sme uverejnili informačný príspevok, v ktorom sme predstavili seba a ciel' nášho pripravovaného výskumu. V priebehu niekol'kých dní sa nám nás kontaktovali matky autistických detí, ktoré boli ochotné s nami na výskume spolupracovat́. Zamedzenie osobného kontaktu sme samozrejme dodržali, rozhovor s našimi štyrmi respondentkami sme realizovali pomocou online komunikácie cez Facebook a telefonicky. Rozhovor pozostával z dvanástich otázok, ktoré sme si pripravili na základe stanoveného hlavného ciel'a výskumu, ktorý je :,,Zistit' ako pandémia CIOVID - 19 ovplyvnila životy rodín s diet'at’om, ktoré má diagnostikovanú poruchu autistického spektre“. Hlavný ciel'sme následne premietli do čiastkových ciel'ov, prostredníctvom ktorých 
sme chceli zistit' ako reagovali deti s autizmom na nútenú sociálnu izoláciu zmeny a d’alšie pandemické opatrenia, ako vnímali pandémiu samotní rodičia a jeden čiastkový ciel' smeroval tiež k zisteniu pripomienok a návrhov rodičov na riešenie situácie počas pandémie COVID -19.

\section{Reakcie detí s autizmom na sociálnu izoláciu a d’alšie pandemické opatrenia}

Špecifikom detí s poruchou autistického spektra je, že pri orientácii sa v sociálnom prostredí,, im vel'mi pomáhajú rituály a pravidelnost'. Tieto deti potrebujú mat' štruktúrovaný nielen deň, ale aj týždeň, či rok (Schramm, 2011, Beyer, Gammeltoft, 2006). Akákol'vek zmena pôsobí na nich natol'ko rušivo, čo môže mat' za následok odmietnutie spolupráce (Cottini, Vivantiho, 2018). Pri formulovaní prvého čiastkového ciel'a sme vychádzali práve z tohto poznania. Zaujímalo nás, ako rodičia reflektujú dopad najväčšej zmeny vyvolanej online vyučovaním a tou bolo rozbitie týždennej štruktúry, pričom ani rodičia týchto detí sa nemali možnost' pripravit' sa na túto zmenu, ako nám potvrdila naša informantka Lucia: ,, Sociálna izolácia spôsobila, že sa denné centrum, ktoré navštevuje môj syn sa zavrelo. $V$ našej rodine nastala zo dňa na deň zmena každodenného režimu celej rodiny“. Podobne sa vyjadrila aj informantka Tereza, ktorá dodala „Vysvetlit’ môjmu synovi, že musíme zostat’ doma a že od dnes neuvidí svojich kamarátov bolo takmer nemožné. Nastali zmeny správania ako je zoýšená agresivita či neochota mojej dcéry komunikovat'so mnou “. Zmeny, ktoré pandemické opatrenia priniesli do života sledovaných rodín sa však týkali širšieho spektra. V prvej vlne pandémie na jar 2020 sa vyžadovalo, aby aj deti s autizmom mali na verejnosti prekrytý nos a ústa. Hygienické pravidlá prirodzene nemohli zachytit’ špecifické potreby všetkých sociálnych skupín. Reakcie detí s autizmom boli často razy pre verejnost' nepochopitel'né. „,Mojej dcére bolo vel'mi t'ažké vysvetlit', čo sa momentálne vo svete deje, bolo pre ňu nepochopitel'né, prečo musí mat́počas nakupovania na tvári rúško. Ochranné pomôcky moja dcéra nerešpektovala a v obchode si ho neustále dávala dole, mala strach."(L'udmila). Rodičia s diet́at́om s poruchou autistického spektra sa museli vyrovnávat' aj s vlastnou nepripravenost́ou na prevzatie úlohy domáceho učitel'a. „,V rodine nastal strach nie len zo strany nášho diet’at́a, ale aj zo strany nás - rodičov, ako budeme svoje dietáa vzdelávat' či vychovávat' d’alej“(Denisa). Dodala posledná matka

\section{Výsledky}

Napriek tomu, že rodičia čelia navonok rovnakému problému, každá rodina je osobitým systémom, ktorý sa od ostatných rodín líši nielen vel'kostou, či štruktúrou rodiny, ale aj individuálnymi potrebami členov rodiny (Levická a kol, 2004).

Sociálna práca ako profesia si za svoj globálny ciel' dala prispievat' ku kvalite života čo najširšieho spektra členov spoločnosti. Situácia vyvolaná ochorením COVID-19 nás však postavila pred situáciu, s ktorou sme ani v globálnom prostredí nemali žiadnu skúsenost'. Rodiny s autistickým dietatótom prirodzene očakávali pomoc nielen od pedagógov, ktorí vzdelávali ich deti, ale od všetkých ostatných odborníkov. Zmapovanie reflektovania pandémie rodičmi týchto detí preto pokladáme za významné v kontexte budúcej intervencie vyvolanej prípadnou tret́ou vlnou pandémie COVID-19, či inou obdobnou situáciou.

Sociálna izolácia zasiahla rodiny a jej jednotlivých členov v rôznych oblastiach, pričom každá z nich má potenciál vychýlit' rodinný systém z homeostázy. Informatka Tereza svojím vyjadrením potvrdzuje silu dopadu pandémie na jej rodinu. „Po zavedení protipandemických opatrení som zostala nezamestnaná, čo ouplyunilo finančný príjem celej našej rodiny. Pomoc opatrovatel'ky už nebola potrebná, zostala som so svojím diet́atom doma“. Pani Denia sa vyjadrila, že „Zo dňa na deň sme boli nutní zostat's mojím synom doma. Musela som zvládat' rolu matky, rolu vychovávatel'ky, rolu učitel'ky a psychologicky môjho diet́at'a." V rodinách s d'alším diet́at'om, či det́mi pribudol d’alší problém a to potreba delit' čas medzi všetky deti. ,,Mám ešte jedno dietá, ktoré je školopovinné. Ustrážit' a obe deti bolo vel'mi náročné. Môj autistický syn si vyžaduje väčšiu pozornost’́a starostlivost' ako diet'a bez postihnutia, ktoré na svojho súrodenca žiarlilo“(Lucia). Zvýšená fyzická, ale najmä psychická únava sa stala súčast́ou života našich respondentiek. „Ja ako matka som začala pocitovat' nie fyzickú ale i psychickú vyčerpanost'“(L'udmila).

\section{Diskusie}

Humanisticky orientovaní sociálni pracovníci a pracovníčky v svojej práci aplikujú Rogersovo presvedčenie, že klient si sebou okrem svojho problému prináša aj jeho riešenie. Viera v klientove schopnosti nájst' riešenia svojich problémov sa tu spája aj s presvedčením, že klient ich odhalením posilňuje nielen odhodlanie vyriešit’ svoje problémy, ale zároveň posilňuje aj svoju autonómiu a sebadôveru(Rogers, 2000, Merry, 
2004, Levická, 2017). Ak umožníme klientovi nachádzat́ vlastné riešenia, pozitívne to ovplyvní aj náš profesionálny vzt́ah.

Našou úlohou je potom len sprevádzat' ich na ceste, ktorú si sami vybrali. Niektoré z odpovedí našich informantiek potvrdzujú tieto tvrdenia. Napr. „Založila by som online komunitu pre všetkých rodičov detí s autizmom. Existuje skupina na Facebooku, $v$ ktorej si rodičia radia navzájom, avšak nie každý rodič autistického diet́at'a o tejto skupine vie.“ (Lucia). Alebo „Ako matka autistického diet'at'a by som privítala pomoc vo forme poradenstva či terapie ako zvládat' súčasnú situáciu“. V oboch týchto prípadoch stačí, aby sociálne pracovníčky a pracovníci spolu s informantkami potom naplánovali ako tieto návrhy preniest' do reality. Trocha náročnejšie sú identifikované potreby a návrhy d’alších informantiek ako „Privítali by sme od štátu vyššiu finančnú pomoc pre rodičov detí s autizmom. Dávky by som použila na kúpu druhého počítača, nakol'ko mám dve deti a potrebujú k štúdiu počítač.“(Tereza) alebo „Navrhla by som zrušenie každoročných formálnych dokladovaní zdravotného stavu môjho diet'at'a, nakol'ko autizmus sa vyliečit' nedá, avšak predkladat’ posudky o zdravotnom stave mojej dcéry musíme každý rok“. (L'udmila)

\section{Záver}

Výpovede našich informantiek potvrdzujú platnost' odporúčaní Cottini, Vivantiho (2018), dodržiavat' štruktúrovaný denný a týždenný režim, aby sa ul'ahčila det́om s poruchou autistického spektra ich sociálna integrácia. Takisto sa potvrdilo, že informantky očakávali a očakávajú pomoc a podporu riešenia ich situácie nielen počas pandémie, ale aj v čase po pandémie. Jedným z predbežných výstupov prebiehajúceho výskumu je, že táto pomoc im ponúknutá nebola. Banks (2020) pritom upozornila na zvýšenú potrebu pomoci a podpory, ktorú môžu naši klienti pocitovat' v súvislosti s nástupom pandémie COVID-19.

Napriek skutočnosti, že predložené zistenia sú len výsledkami pilotnej fázy výskumu, potvrdzujú, že pandemické opatrenia zasiali rodiny, ktoré vychovávajú diet́a s poruchou autistického spektra pomerne široko. Zároveň sme prostredníctvom získaných dát identifikovali oblasti, o ktoré náš d’alší výskum chceme rozšírit', aby sme získali dostatok dát na porozumenie situácie týchto rodín a následne na plánovanie efektívnych možností intervencie.

Na základe rozhovorov s rodičmi detí s autizmom sa nám podarilo zistit', že aktívne využívajú svojpomocné skupiny na internetovej platforme Facebook. Sociálne online skupiny hodnotia vel'mi pozitívne. V skupinách sa združujú rodičia detí autistov, ktorí si odovzdávajú rady, informácie či skúsenosti, ktoré doposial'získali alebo nadobudli počas každodenného života. Fungovanie online priestoru má viac pozitív. Členom skupiny sa môže stat' každý človek, čo ma založené užívatel'ské konto na sociálnej sieti Facebook. Skupina je prevádzkovaná samotnými používatel'mi, ktorý do nej prispievajú denne svojimi príspevkami, otázkami či informáciami, ktoré zdielajú verejne, zadarmo ostatným členom skupiny.

\section{Literatúra}

AUTIZMUS, (2021). https://www.facebook.com/groups/2093944040645664

BANKS, S. CAI, T., de JONGE, E., SHEARS, J., SHUM, M., SOBOČAN, A. M., STROM, K., TRUELL, R., URIZ, J. M., WEINBERG, M. (2020). Practising ethically during COVID-19: Social work challenges and responses.International Social Work, 63(5):569-583. https://doi.org/10.1177/0020872820949614

BEDNÁŘ, Vojtěch. (2011). Marketing na sociálních sítích. Brno: Computer Press, a.s.LOSEKOOT,

BEYER, J., GAMMELTOFT, L. (2006). Autismus a hra. Praha: Portál. ISBN 80- 7367-157-3.

COTTINI,L., VIVANTIHO, G. (2018). Autizmus. Čo a ako robit’́ s det'mi a mládežou v škole. Bratislava: NOXI, ISBN 978-808-11145-26

GILLBERG, CH., PEETERS, T. (1998). Autismus - zdravotní a výchovné aspekty. Praha: Portál. ISBN 807178-201-7

HENDL, J. (2015). Přehled statistických metod spracování dat: Analýza a metaanalýza dat. Praha : Portál. ISBN 978-80-262-0981-2.

KORONA, (2021). Aktuálne opatrenia. https://korona.gov.sk/platne-hygienicke-opatrenia/

LEVICKÁ, J. (2017). Poradenstvo a advokácia : dva spôsoby profesionálnej intervencie.Trnava : Fakulta zdravotníctva a sociálnej práce Trnavskej univerzity v Trnave. ISBN 978-80-568- 0038-6

LEVICKÁ, J. a kol. (2004). Sociálna práca s rodinou. Trnava: MOSTYa TU , ISBN: 808-907-4936-2

MERRY,T. (2004). Naučte sa byt' poradcom. Bratislava: IKAR, ISBN: 80-551-0768-8 
MINISTERSTVO VNÚTRA SLOVENSKEJ REPUBLIKY, (2020). Spoločná Zodpovednost' na Slovensku.https://www.minv.sk/swift_data/source/verejna_sprava/vestnik_vlady_sr_rok_2021/vyhlaska_205.pdf

NÁRODNÝ PORTÁL ZDRAVIA_. (2021). Spektrum autistických chorốb. https://www.npz.sk/sites/npz/Stranky/NpzArticles/2013_06/Spektrum_autistickych_poruch,_Aspergerov_syndrom.aspx?did=1\&sdid=3\&tuid=0\&

PRIATELIA AUTISTOV, (2021). https://www.facebook.com/groups/187403834603424

ROGERS, C. (2000). Klientom centrovaná terapia. Modra: Persona, ISBN: 80-96798-03-0

SCHRAMM, R. (2011). Motivation and Reinforcement: Turning the Tables on Autism. Pro-ABA. ISBN 978-14477-4836-6.

STATISTA. (2020). „Distribution of Facebook users worldwide as of October 2020, by age and gender.“ Statista. https://www.statista.com/statistics/376128/facebook-global-userage-distribution/

VYHNÁNKOVÁ, M. (2019). Jak na sítě: Ovládněte čtyři principy úspěchu na sociálních sítích. Brno: Jan Melvil Publishing

ŽIAKOVÁ, K. a kol. (2009). Ošetrovatel'stvo - teória a vedecký výskum. Martin : Osveta,2009. ISBN 978-808063-304-2.

\section{Informácie o autoroch}

\section{Mgr. Erika Ochabová}

Pôsobím ako interná doktorandka na Univerzite sv. Cyrila a Metoda v Trnave, Katedra Sociálnych služieb a poradenstva, Fakulta Sociálnych vied od septembra 2020. Svoje štúdium na Univerzite sv. Cyrila a Metoda v Trnave začala v roku 2015. Úspešne som získala titul Bakalár a neskôr titul Magister. V súčasnosti študujem 2. ročník doktorandského štúdia so zameraním na odbor sociálna politika. Ako interná doktorandka sa vo svojej dizertačnej práci sa zaoberá skúmaním Identifikácie Etického kódexu v priamej praxi s klientom. 